\title{
“IT'S GONNA BE SOME DRAMA!”: A CONTENT ANALYTICAL STUDY OF THE PORTRAYALS OF AFRICAN AMERICANS AND HISTORICALLY BLACK COLLEGES AND UNIVERSITIES ON BET'S COLLEGE HILL
}

\author{
Siobhan E. Smith \\ Dr. Jennifer Stevens Aubrey, Dissertation Supervisor
}

\begin{abstract}
One way the mainstream public comes to learn about Historically Black Colleges or Universities is through the media. Reality television show College Hill, aired by Black Entertainment Television, appeared to have the goal of presenting the unique aspects of HBCU life. In spite of this objective, some critics and scholars argued the program fell short, relying on familiar and negative stereotypes to present the majority AfricanAmerican casts, to the detriment of the reputation of these institutions. To explore this possibility, a content analysis of Seasons 3 and 4 of the program (30 episodes) was conducted. It was found that in general, behaviors and traits of the African-American cast members both supported and contradicted previously established, culturally-based stereotypes of African Americans, and that their appearances suggested normalcy. However, African-American women were portrayed in a significantly more negative manner than their male counterparts. In addition, out of the 327 scenes, only 43 (13.1\%) had a reference to the HBCU; 30 scene-level references (69.8\%) were to academic goals. Further, while the show mostly depicted the cast members interacting independently of the HBCU backdrop, it appears when the HBCU was referenced on the scene-level, most of these references portray academic, rather than social, concerns. Contrary to the literature regarding College Hill, instances of goals occurred statistically significantly more than instances of anti-goals. In addition, all of these references were considered positive on the episode-level. These findings suggest it is possible that some of the negative portrayals of the cast members might become inseparable from the portrayal of the HBCUs in the mind of the viewer.
\end{abstract}

